Article

\title{
Political Storytelling on Instagram: Key Aspects of Alexander Van der Bellen's Successful 2016 Presidential Election Campaign
}

\author{
Karin Liebhart * and Petra Bernhardt \\ Department of Political Science, University of Vienna, 1010 Vienna, Austria; E-Mails: karin.liebhart@univie.ac.at (K.L.), \\ petra.bernhardt@univie.ac.at (P.B.) \\ * Corresponding author
}

Submitted: 31 May 2017 | Accepted: 27 October 2017 | Published: 21 December 2017

\begin{abstract}
This article addresses the strategic use of Instagram in election campaigns for the office of the Austrian Federal President in 2016. Based on a comprehensive visual analysis of 504 Instagram posts from Green-backed but independent presidential candidate Alexander Van der Bellen, who resulted as winner after almost one year of campaigning, this contribution reconstructs key aspects of digital storytelling on Instagram. By identifying relevant image types central to the self-representation of the candidate, this article shows how a politician makes use of a digital platform in order to project and manage desired images. The salience of image types allows for the reconstruction of underlying visual strategies: (1) the highlighting of the candidate's biography (biographical strategy), (2) the presentation of his campaign team (team strategy), and (3) the presentation of the candidate as a legitimate office holder (incumbent strategy). The article thus sheds light on visual aspects of digital storytelling as relevant factor of political communication.
\end{abstract}

\section{Keywords}

digital platforms; Instagram; political communication; presidential election campaigns; storytelling; visual imagery; visual strategies

\section{Issue}

This article is part of the issue "Visual Communication in the Age of Social Media: Conceptual, Theoretical and Methodological Challenges", edited by Uta Russmann (FHWien der WKW University of Applied Sciences for Management \& Communication, Austria) and Jakob Svensson (Malmö University, Sweden).

(C) 2017 by the authors; licensee Cogitatio (Lisbon, Portugal). This article is licensed under a Creative Commons Attribution 4.0 International License (CC BY).

\section{Introduction: Digital Storytelling in Political Campaigns-The Example of Austria}

The inauguration of Alexander Van der Bellen as Austria's ninth Federal President on 26 January 2017 was preceded by an emotional election campaign. This campaign lasted almost a year and can be considered extraordinary-not only due to organizational circumstances like the annulment of the runoff by the Austrian Constitutional Court on 1 July 2016 and the postponement of the runoff vote from 2 October to 4 December 2016, but also due to increased modernization and professionalization processes regarding campaign communication. This included an extension of campaign channels and, along with it, a diversification of target group messages. Especially the campaigns of the runoff candidates Norbert Hofer (Austrian Freedom Party/FPÖ) and Alexander Van der Bellen (Green-backed but independent) made use of various digital platforms such as Facebook, Twitter, or Instagram to directly address target groups, bypass traditional media, or set the agenda for media coverage.

This article uses the diversification of digital platforms in the 2016 election campaigns for the office of the Austrian Federal President as a starting point for an analysis of Alexander Van der Bellen's Instagram account as campaign channel. One has to consider the limits of such an approach in that it may fail "to recognize the diverse, fragmented, and complex modern media environ- 
ment, of which a single media platform is only a small part" (Bode \& Vraga, 2017, p. 1). However, focusing on a single digital platform can be "enormously useful, in that it gives us a better understanding of the use, the content, and the effects of specific media platforms" (Bode \& Vraga, 2017, p. 1).

Van der Bellen's campaign made use of transmedia (Jenkins, 2006, 2010) storytelling strategies aimed at amplifying the reach of campaign messages through synergistic use of multiple social media accounts and analogue media (e.g., political posters). Nowadays, political "storytellers use digital platforms alongside a range of other delivery channels so that each piece of media adds something significant to the overall experience of the story world" (Jenkins, 2017, p. 1062).

Digital Storytelling is not a new phenomenon (Kavoori, Lashley, \& Creech, 2017, p. 1057). Henry Jenkins $(2017$, p. 1061) explains that it "could include stories generated via digital tools, stories that involve various forms of networked participation or interactivity, stories that are distributed via digital platforms, or stories that are consumed on digital platforms". For Jenkins (2017, p. 1062), "storytelling practices persist because they are meaningful to those who produce and consume them". Kevin J. Hunt (2015) states that "an inevitable part of political rhetoric relies upon telling stories". The latter help potential voters to relate to rather abstract political ideas (Hunt, 2015) as well as political candidates: "People connect with candidates...the same way they connect with books and movies; they simply won't engage without a good story" (Weber, 2016).

Storytelling in politics generally relies on a wide range of strategies to shape personal and political narratives. Such strategies comprise references to biographically relevant settings and locations, family histories, or the use of personal photos within the context of the political campaign (e.g., so-called throwback photos on Instagram). Austrian presidential candidate Alexander Van der Bellen used the story of the homeland (in German: Heimat) as a central narration of his campaign. The Green-backed candidate defined homeland as inclusive concept in order to differentiate himself from his right-wing contestant Norbert Hofer (Austrian Freedom Party/FPÖ). For Van der Bellen, home can be the Tyrolean valley where his family found refuge during his childhood, but also some place in the European Union. According to this definition, "feeling home" is not bound to a place, but to a sense of belonging. The story of the Van der Bellen family is connected with the campaign narrative and becomes a focal point of a personalized storytelling strategy on a verbal and visual level.

Political and communication scholars alike stress that a stronger personalization of politics and political communication (cf. Garzia, 2014; Karvonen, 2009; Kriesi, 2012; McNair, 2016; Van Aelst, Sheafer, \& Stanyer, 2011) supports the "growing centrality of the individual" (Balmas \& Sheafer, 2016, p. 944) in contemporary election campaigns. Along with "centralized media personaliza- tion (or concentrated visibility)" (Balmas \& Sheafer, 2016, p. 945), a shift from topic-based to personality-based campaigns also affects the visual presentation of politics (Keim \& Rosenthal, 2016, p. 313; Van Aelst et al., 2011). Furthermore, the increasing influence of non-political topics tends to blur boundaries between the political and the non-political. Holtz-Bacha, Langer and Merkle (2014, p. 156) also stress this "shift in emphasis from the political to the personal sphere". This is particularly relevant for a strongly personality-influenced vote like the one for the Austrian Federal Presidency, which is the only nationwide ad personam election in Austria.

This article builds on previous studies while placing special emphasis on the visual component of digital storytelling. While adding to the steadily growing scientific literature on the strategic function of social media platforms in election campaigns-which started in the early 2000s after being boosted by the successful campaign of Barack Obama in the US (Keim \& Rosenthal, 2016)-the article also reacts to a request for research to be conducted on the role of visibility and imagery in political communication (cf. Schill, 2012). This research gap must be taken seriously in the light of a growing shift of communication into the so-called "visual web", which particularly privileges visual forms of communication on digital platforms. In an article on Instagram analyses, Tim Highfield and Tama Leaver (2016, p. 48) therefore declared the visual aspect to be a central topic of social media research. While previous studies have already discussed the fact that "political messages are communicated [in] oral, written and visual language" (McNair, 2016, p. 506) and provided, for instance, quantitative findings such as the presence of different political actors in photographs, qualitative approaches to the analysis of visual imagery and strategies have not yet been applied to a sufficient extent. This article increases the existing literature by a qualitative-interpretative discussion of the visual dimension of digital storytelling.

The empirically based contribution provides an indepth visual analysis of the strategic self-presentation of the successful Austrian presidential candidate. Strategic self-presentation refers to the intentionality of selection and presentation routines on Instagram. Politicians employ personal photographers who have privileged access in official and semi-private situations of the campaign. The resulting photos are meticulously selected and arranged (e.g., with texts, hashtags, links) by the campaign team: "Public relations (PR) personnel are curtailing access to political leaders while planning, producing, selecting, and distributing their own favorable photos and videos....These managed visuals can reflect serious matters and routine government business, such as politicians meeting with their counterparts or working in their offices, and can offer a glimpse of otherwise private moments" (Marland, 2012, p. 215). The reconstruction of selection routines can provide important information about the relevance of visual imagery for the candidate and the overarching campaign story. 
The article first examines how the incumbent president presented himself on his Instagram account during the whole campaign cycle, in which situational moments and contexts he was shown, and which interactional patterns had dominated his visual portrayal. The second aim of the study is to examine which storytelling strategies the candidate pursued in his choice of visual imagery. The analysis covers the whole range of visual imagery that was posted on Instagram including photographs, graphics, animated graphics (GIFs), image-text combinations, and short videos. The aim of the study was to gain information on the "selection and portrayal routines" (Grittmann, 2012, p. 135) ${ }^{1}$ of the strategic visual communication of a politician during an election campaign. The study covers the period of almost twelve months, from 1 January to 4 December 2016.

\section{Researching Instagram: Research Framework, Corpus, and Methodological Design}

Researching Instagram as a tool in political communication is a relatively new phenomenon. The platform began to operate in 2010 and has constantly gained popularity since then. Instagram is currently one of the fastest growing social networks. The photo-sharing app has been counted among the most famous social networking sites world wide with over 800 million monthly active accounts as of September 2017, and has ranked number seven in terms of active users (de.statista.com, 2017a). In Austria, Instagram use has increased from 340,000 active accounts in February 2016 to 1,000,000 active accounts in December 2016, and 1,600,000 active accounts in March 2017 (de.statista.com, 2017b).

The app allows users to add filters to pictures and videos and to distribute them on the platform and in other social media. Instagram users can follow other users and search, comment, or like other people's photos. Instagram, which became part of Facebook in August 2012 , has constantly been upgraded with new functions such as the introduction of the photo card tool, which is able to sort Instagram photos by place of origin, the integration of the stories feature, which allows for the creation of video or photo sequences that are only visible for 24 hours, and recently the introduction of new face filters. Since May 2017 location stories and hashtag stories help users find stories relating to individual interests (instagram-press.com, 2017).

In 2012, The Heritage Foundation (Sylvester, 2012) asserted that politicians had become aware of the communicative power of Instagram:
By jumping into already-buzzing communities such as Instagram, political leaders can harness fresh energy by getting personal and taking advantage of possibilities to connect with both influential personalities and everyday Americans. (Sylvester, 2012)

In the US presidential election campaign in the same year, both Barack Obama and his opponent Mitt Romney made use of the app "to give citizens a different, behindthe-scenes look at what you might not see on other platforms" (Sylvester, 2012) and to directly address different target groups.

The praise that Instagram has received as political communication tool has tended to focus on how it provides politicians with a concise, direct method of sharing their message and enhancing their image, and how it helps citizens feel personally connected to government and its leaders. (Glantz, 2013, p. 695)

Despite the growing popularity and importance of Instagram, research has been relatively limited compared with other platforms like Twitter (cf. Laestadius, 2017, p. 573). A literature review on the use of Instagram in election campaigns and political communication indicated that (1) only very few studies are using Instagram to understand political communication, and (2) that most research focuses on the strategic context of Instagram usage (e.g., Filimonov, Russmann, \& Svensson, 2016; Russmann \& Svensson, 2017) rather than on the specific meanings made by visual imagery (e.g., Muñoz \& Towner, 2017).

Visual imagery on politicians' Instagram accounts as material pictures, which are the basis of immaterial images, can be used "as first indicators for an approximation to the study of images" (Müller \& Geise, 2015, p. 36). ${ }^{2}$ However, the use of Instagram in political communication as both a means of staging a political personality and a form of image management has not been sufficiently studied yet. According to German communication scholars Marion G. Müller and Stephanie Geise, "staging may generally be defined as a public exhibition of a work, event, person or object" (Müller \& Geise, 2015, p. 32). ${ }^{3}$ Associated with the staging of a politician are presentation techniques in order to "make it appear visually before an audience... and to provide it with a corresponding visual interpretation frame" (Müller \& Geise, 2015). ${ }^{4}$ In professional political communication efforts, strategic stagings as "consciously shaped reality" (Müller \& Geise, 2015, p. 34$)^{5}$ have growing influence on the production, selection, and dissemination of visual mate-

\footnotetext{
${ }^{1}$ Original quote in German: “Auswahl- und Darstellungsroutinen” (Grittmann, 2012, p. 135).

2 Original quote in German: Materielle Abbilder können "als erste Anhaltspunkte zur Annäherung an die Erforschung von Images herangezogen werden" (Müller \& Geise, 2015, p. 36).

3 Original quote in German: “Dabei kann eine Inszenierung allgemein als öffentliche Zurschaustellung eines Werkes, Ereignisses, einer Person oder eines Objekts definiert werden" (Müller \& Geise, 2015, p. 32).

${ }^{4}$ Original quote in German: Präsentationstechniken der Inszenierung, um etwas "für ein Publikum visuell in Erscheinung zu bringen und es dabei mit einem entsprechenden visuellen Interpretationsrahmen zu versehen" (Müller \& Geise, 2015, p. 32).

${ }^{5}$ Original quote in German: "bewusst gestaltete Realität" (Müller \& Geise, 2015, p. 34).
} 
rial in creative terms, which helps candidates appear in a positive light. Stagings are primarily used to consciously shape intended images (Müller \& Geise, 2015, p. 35; cf. also McNair, 2016). The term image refers to "a mental construct of an object or a person, which is generated on the basis of consciously or unconsciously perceived (media) images, facts, associations, experiences or judgments" (Müller \& Geise, 2015, p. 35). ${ }^{6}$

The production, selection, and distribution of visual imagery in terms of image management by politicians may thus help to shape "the image of persons or groups of persons, their behaviour and lifestyle as well as their character traits" (Grittmann, 2012, p. 128). In this context, it should be noted that images as a visual imagination (Müller \& Geise, 2015, p. 35; italics in original text) "are not objective, unequivocal and comprehensive, but subjective and, hence, ambiguous, selective, and often stereotyped and unconscious" (Müller \& Geise, 2015). ${ }^{7}$

Communication scholar Elke Grittmann (2007) has convincingly shown that the visual presentation of politics is condensed to a repertory of visual imagery, which is constructed by "selection and, thus, attribution of meaning" (Grittmann, 2012, p. 142). ${ }^{8}$ This observation applies not only to journalistic photo-reporting, but also to the strategic self-representation of politicians. Among typical motifs we find formal or informal speech, official encounters with other politicians, meetings, talks, or the staging of closeness to citizens (Grittmann, 2012, pp. 142-144).

The framework outlined above leads to the research question how Alexander Van der Bellen used his Instagram account during the 2016 presidential election campaign in order to project and manage desired images, and which visual imagery he emphasized for that purpose.

The study drew on several Instagram posts of Alexander Van der Bellen's verified account (@vanderbellen, instagram.com/vanderbellen) during the Austrian presidential election campaign $2016(n=504)$. The full sample comprised posts between 8 January 2016 (first entry) and 4 December 2016 (last entry on election night). Since his victory, Van der Bellen's Instagram account has continued to serve as the official account of the Federal President. The unit of analysis for this study was the single Instagram post: photos, short videos, graphics, animated graphics (GIFs) with captions and hashtags. User comments were not included in the analysis due to the research focus on strategic visual self-presentation.

Tim Highfield and Tama Leaver (2016, p. 49) emphasize that visual content requires "researchers to broaden and diversify the way social media is examined and addressed" in order to make sense of the polysemic struc- ture of visuals in concert with text (Highfield \& Leaver, 2016). The posts were screen-captured, archived, and manually annotated by a coder experienced with visual content. The annotation particularly focused on actors, settings, and depicted constellations of interactions.

The methodological design employed was an image type analysis, a method developed by the German communication scholars Elke Grittmann and Ilona Ammann $(2009,2011)$. It allows to classify visual content as specific image types according to their motifs. While the method was originally developed for the analysis of photo-journalistic routines and selection criteria (Grittmann \& Ammann, 2011, p. 167), the image type analysis may also be applied to strategic visual imagery of politicians in order to make statements on routines and selection criteria in the choice of imagery.

The image type analysis follows a two-step approach: where conclusions on "patterns and strategies are drawn, a quantitative approach is required whereas the analysis of meanings and symbols calls for a more qualitative procedure" (Grittmann \& Ammann, 2011, p. 165). ${ }^{9}$ The development of image types requires an in-depth knowledge of the selected visual content (Grittmann \& Ammann, 2011, p. 169) and is oriented around the process of the iconographic approach developed by Erwin Panofsky in the 1920s and 1930s. This approach is based on a three-step procedure: a pre-iconographic description, an iconographic analysis, and an iconological interpretation (cf. Panofsky, 1972, pp. 1-17). This contribution specifically refers to the process of iconographic analysis.

The material was first classified by recurring visual motifs in order to identify topic domains of the full sample. Research suggests that visual portrayals of politicians tend to follow certain archetypes (cf. Bucy \& Grabe, 2009; Grittmann, 2007, 2012; Müller, 1997). Such archetypes like meeting with supporters and mass appeal, presenting the family, or meeting with fellow politicians provide a framework for the classification of the visual material according to known categories. Nevertheless, it is important to consider that most of these archetypes were derived from the journalistic presentation of political candidates. Bucy and Grabe (2009) have focused on the presentation of presidential candidates in network news coverage of US elections. Grittmann (2007) has focused on press photography in Germany. For this reason, known categories do not necessarily reflect selection and presentation routines of political selfpresentation on Instagram. For this study, known categories were complemented by inductively generated categories that consider the specific context of personalized campaign storytelling (e.g., the importance of the personal background of the candidate and his connect-

\footnotetext{
${ }^{6}$ Original quote in German: Ein Image bezeichnet "ein mentales Konstrukt von einem Objekt oder einer Person, das auf Basis bewusst oder unbewusst wahrgenommener (Medien-)Bilder, Fakten, Assoziationen, Erfahrungen, oder Bewertungen beim Rezipienten entsteht" (Müller \& Geise, 2015, p. 35).

7 Original quote in German: Als "visuelle Vorstellung" sind Images "nicht objektiv, eindeutig und umfassend, sondern subjektiv und damit mehrdeutig, selektiv, häufig stereotyp und häufig unbewusst" (Müller \& Geise, 2015, p. 25).

8 Original quote in German: "Auswahl und Bedeutungszuweisung” (Grittmann, 2012, p. 142).

${ }^{9}$ Original quote in German: Wo Schlussfolgerungen über “Muster und Strategien gezogen werden, ist ein quantitatives Vorgehen nötig, die Analyse von Bedeutungen und Symboliken verlangt jedoch ein stärker qualitatives Vorgehen" (Grittmann \& Ammann, 2011, p. 165).
} 
edness with the country of which he wanted to be elected president).

Image types differ from motifs in terms of their degree of abstraction. They reduce the meaning of individual motifs to their central message (Grittmann \& Ammann, 2011, p. 170) and therefore also condense complex political contexts. Since according to Grittmann and Ammann (Grittmann \& Ammann, 2011, p. 170) image types need to be homogeneous internally and heterogeneous externally, motifs with the same implicit statement are grouped together on the basis of generalized meanings (Grittmann \& Ammann, 2011). To give an example: While settings and actors during a presidential campaign may vary (e.g., journalists and studio settings when it comes to the image type media work), the essential message remains the same (in this case: media interest in the candidate).

After the classification process, the image types were quantified and interpreted (cf. Figure 2). This allows for conclusions regarding "selection and production routines and the interpretation frames, ideas and ideologies transported by images" (Grittmann \& Ammann, 2011, p. 171)..$^{10}$ Furthermore, selection routines provide important information about the relevance of an image type for the overarching campaign story.

\section{Selected Results of the Image Type Analysis}

Alexander Van der Bellen's Instagram account was regularly updated throughout the whole study period. Chronological posts were organized around relevant campaign events. This gave Instagram the function of a visual diary, which documented campaign activities, referred to upcoming events (e.g., press conferences, public appearances, site visits, cf. Figure 1) or presented new articles in the fan shop (fanderbellen.at; page no longer accessible). By posting not only photos and short videos, but also graphics and animated graphics (GIFs) in the corporate design of the campaign, Van der Bellen's Instagram strategy made use of the full spectrum of visual imagery. The regular use of text and hashtags provided relevant context for the posts.

In Figure 2, the following image types were emphasized on Alexander Van der Bellen's Instagram account:

The image type campaign $(n=119)$ includes visual imagery that presents the candidate in campaign-related activities and conveys information that is relevant to the campaign (e.g., survey results) as well as advertising material. It also comprises the collection of supportive declarations signed by voters, the distribution of campaign material, speeches delivered at party rallies, or posts of survey results. Van der Bellen's account staging underscored his election campaign staff and his good standing with young supporters and volunteers. Further, Van der Bellen's campaign referred to the release of new campaign posters or announced public debates or performances (e.g., the "Presidential Rave 2.0" in August 2016).

The image type media work $(n=79)$ comprises visual imagery that shows the candidate during interviews or press conferences, or at events organized by media representatives (e.g., panel discussions). Among these

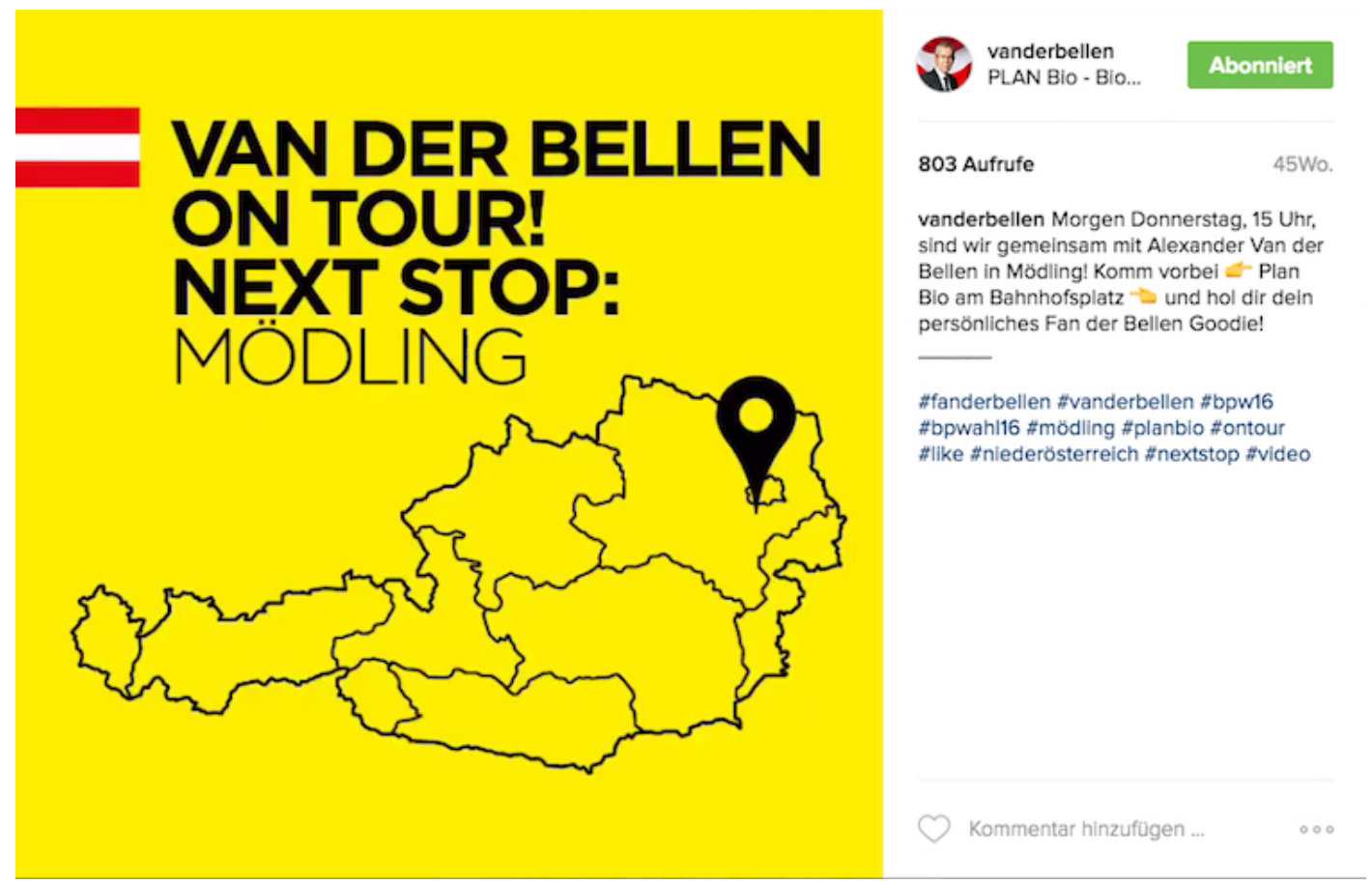

Figure 1. Van der Bellen on tour, posted on 6 April 2016.

\footnotetext{
10 Original quote in German: Schlussfolgerungen bezüglich "Selektions- und Produktionsroutinen sowie die über Bilder vermittelten Deutungsrahmen, Ideen und Weltanschauungen" (Grittmann \& Ammann, 2011, p. 171).
} 
Quantification of image types $(n=504)$

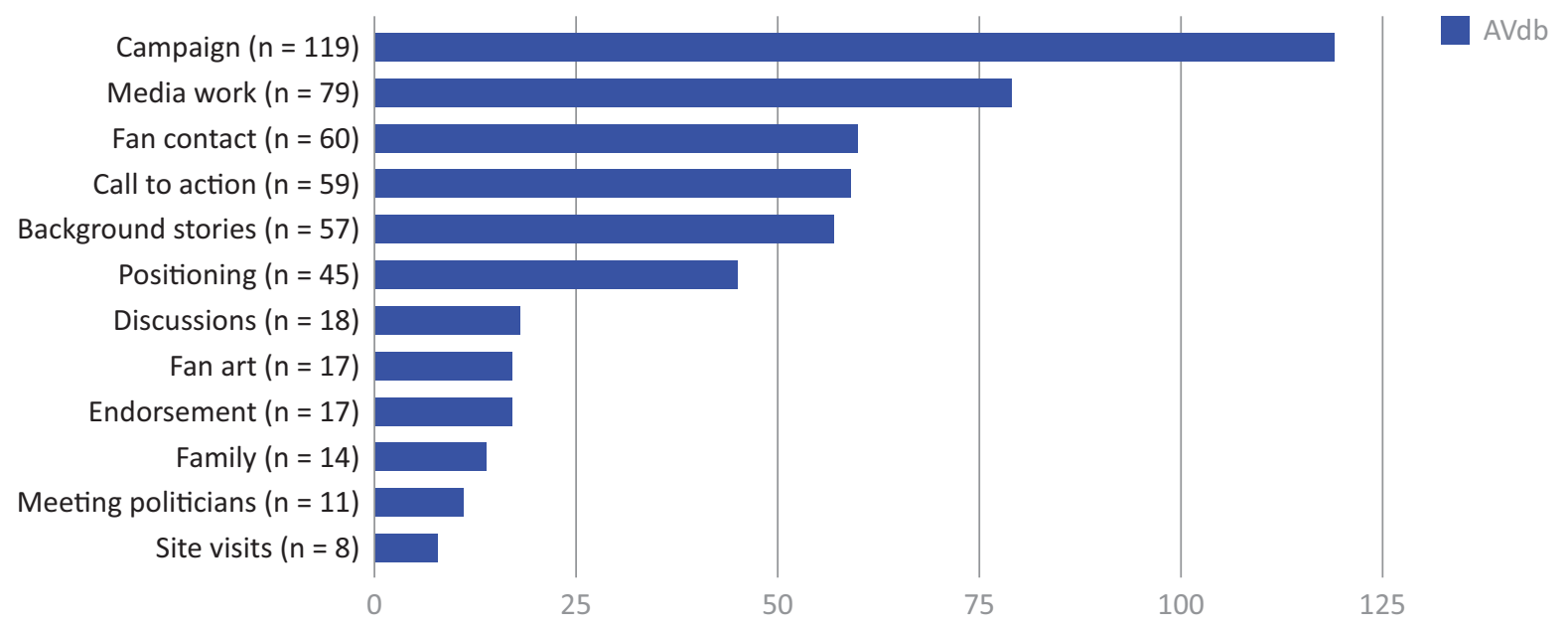

Figure 2. Quantification of image types on Alexander Van der Bellen's Instagram account.

are studio settings, the presence of cameras and microphones, and talks with journalists. This image type suggested an ongoing media interest throughout the whole campaign cycle.

The image type fan contact $(n=60)$ defines and emphasizes specific target groups. It includes photo material showing the candidate as he mingles with people from various segments of the population, where everybody in the picture is engaged in a conversation or posing for a photo or taking a "selfie" with the candidate. A further image type is fan art $(n=17)$. Relevant photo material shows gifts received from fans and stages the gift presentation to express the candidate's popularity with constituents. Van der Bellen, for example, received heartshaped gingerbread with an inscription, a photo of a cat sitting beside Van der Bellen promotion stickers (in August 2016), or a photo of a dog with a Van der Bellen bonnet (in November 2016).

The image type call to action $(n=59)$ comprises visual imagery that explicitly invites users to support the campaign in various ways. A call to action usually comes in a text format which may be inserted in the picture as a quotation or integrated in the accompanying text. In Van der Bellen's campaign, special graphics or animated graphics (GIFs) were produced in the corporate design of the campaign to ask users to volunteer, participate in public events, make donations, or cast their votes.

The image type background stories $(n=57)$ can be described as the most interesting image type emphasized on Instagram during the Austrian presidential election campaign. This category comprises visual imagery which presents the candidate as a person rather than a political figure, places him/her in an individual, biographical context, emphasizes his/her personal attributes (cf. Balmas \& Sheafer, 2016, p. 948) and indicates the politician's "private" interests and priorities. This image type particularly supports personalization because it "refers to heightened attention devoted to the personal characteristics and private lives of candidates" (Holtz-Bacha et al., 2014, p.160). On Instagram, background stories with photos presented Alexander Van der Bellen in semiprivate moments, or in his youth and early years in socalled throwback photos. As emphasized by his throwback photos, Van der Bellen gave special importance to his hiking hobby in his staging of mountain landscapes and himself hiking. Van der Bellen was shown several times as a child with his parents in the mountains (e.g., throwback photo in May 2016) or as a young adult with his sister (cf. Figure 3). ${ }^{11}$ Hiking was the Tyrolean mountains is closely linked to the homeland (in German: Heimat) motif, which Van der Bellen intensively emphasized and reframed during the election campaign and presented as an inclusive concept.

Background stories are used to "normalize" political candidates and to project authenticity. Hobbies and other pastimes indicate aspects of their personality outside the political arena or from before their political career. Van der Bellen was depicted as a passionate reader. On one occasion, passing time between two press meetings, he was shown browsing in a bookshop (February 2016) or on a trip from Graz back to Vienna reading a Donald Duck comic book (in German: Lustiges Taschenbuch) (April 2016, cf. Figure 4).

The candidate's enthusiasm for the cartoon character Donald Duck was a recurrent theme for Van der Bellen. On a trip to Brussels, for instance, he was depicted with a Donald Duck figure (March 2016). Hobbies like solving Sudoku puzzles (e.g., in November 2016) or passions like drinking coffee were also displayed (e.g., in January, March and June 2016, cf. Figure 5).

Another recurring topic was Van der Bellen's interest in soccer. He attended games in a Viennese Soccer Stadium (for instance, watching the team of Rapid Vienna in July 2016 or the Austrian national soccer team in October

\footnotetext{
11 Throwback photos can show family members (e.g., Van der Bellen's sister), but nevertheless classify as background stories due to their captions and the importance attributed to the Tyrolian mountains, the homeland (in German: Heimat) motif and Van der Bellen's passion for hiking.
} 


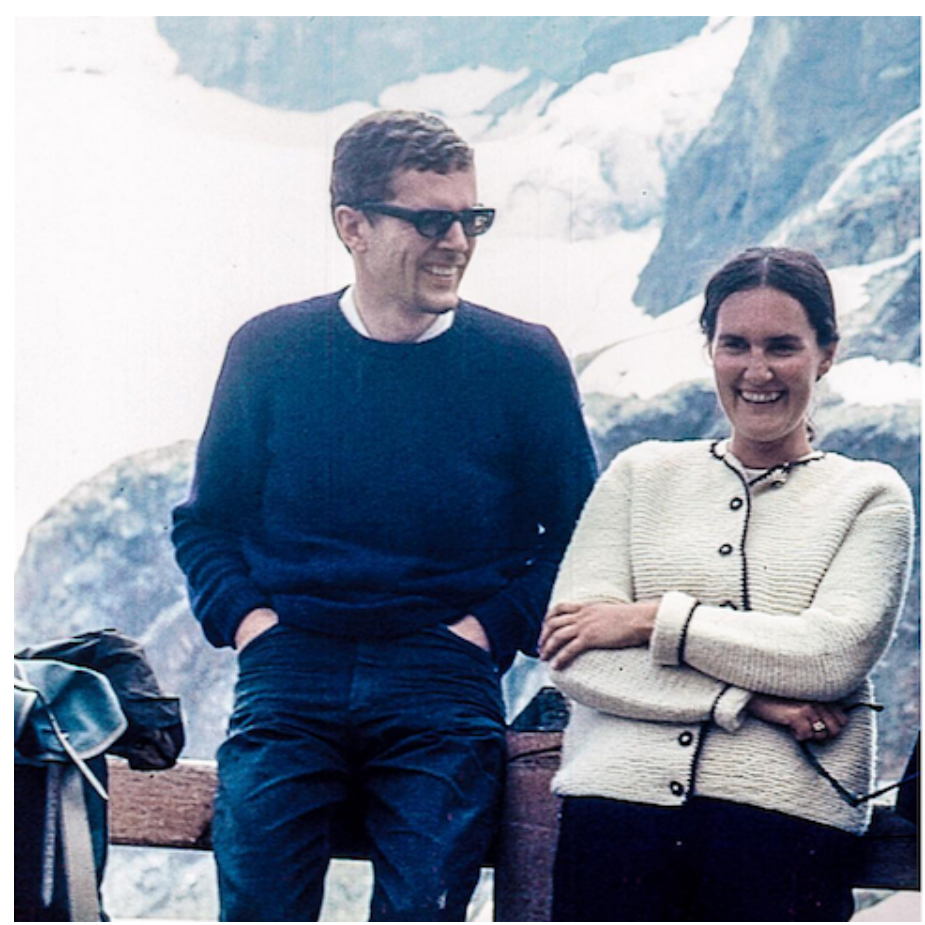

vanderbellen Heute wie damals: In die Berg is er gern! a Alexander Van der Bellen als junger Student mit seiner Schwester Nanni auf der Kaunergrathütte in den Ötztaler Alpen. Bisch a Tiroler, bisch a Mensch. (3)

\#tbt \#throwbackthursday \#vanderbellen \#tirol \#alps \#kaunergrat \#aufiaufnberg \#wandern \#memory \#instamemory \#family \#bergfex \#sunglasses

neongreennetwork Uhhhh

vanderbellen @raffael___ Stimmt! 8 Liebe Grüße vom Team.

lenastickler @palomanodari $\Theta$

pausenkasperl @blumentheater wie Manuel rubey!

Kommentar hinzufugen

Figure 3. Throwback photo of Alexander Van der Bellen, posted on 4 February 2016.

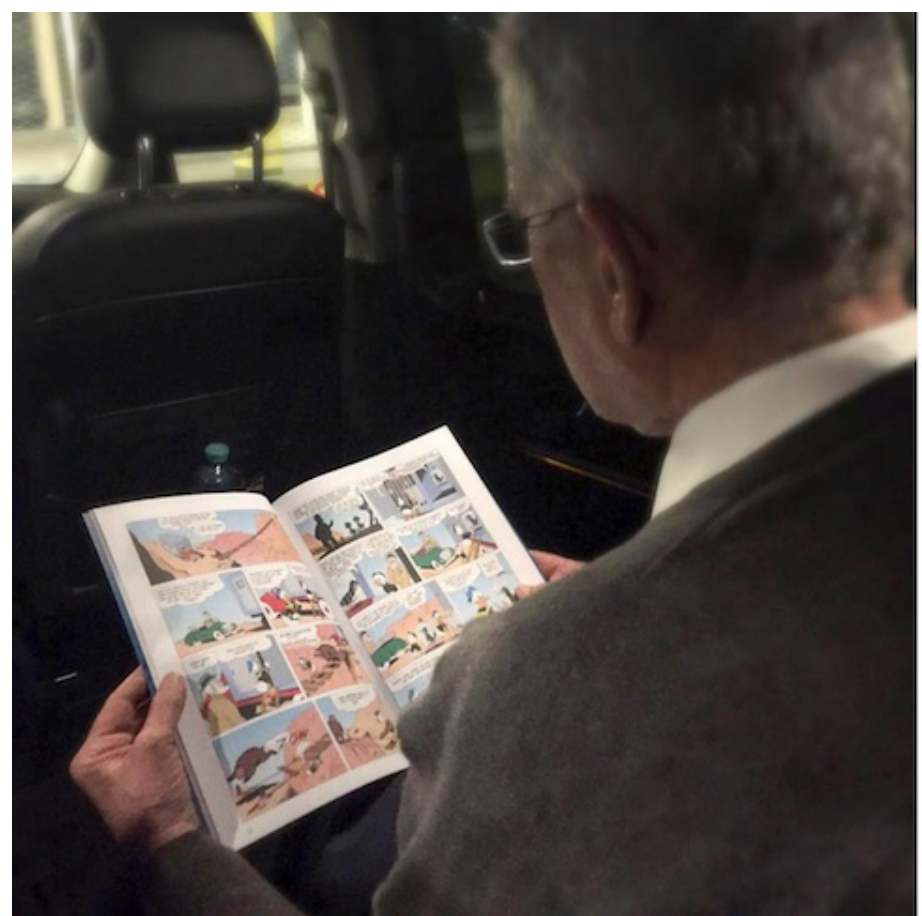

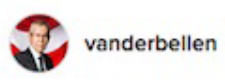

Gefällt $286 \mathrm{Ma}$

vanderbellen Das war ein guter Abend in Graz! Danke fur das große Interesse an der Diskussion im akleinezeitung Salon. Jetzt geht's zurück nach Wien - für die Reiselektüre ist gesorgt. (.)

\section{\#vanderbellen \#ontour \#ontheroad} \#travel \#reise \#graz \#wien \#donald \#entenhausen \#carlbarks \#lektüre \#like \#entspannungsmodus \#bpw16 \#bpwahl16

austrian_obelix Der lese Stil gefält mir vanderbellen @byrdpsi dit

enemenemimi wer donald duck mag MUSS ein guter präsident werden (ce vanderbellen @enemenemimi Hehe. (4) milophotoart nice :) floskel_

Kommentar hinzufugen ...

Figure 4. Reading a Donald Duck comic book, posted on 11 April 2016.

2016), watched a game on a television screen before an interview (in May 2016), or posed for photos with soccer fans in July 2016 and in October 2016.

The image type positioning $(n=45)$ includes visual imagery which points to political issues and causes of the candidate, explains his understanding of the presidential role, and helps him to position himself on the political scale. By using photo-text combinations, quotations on a variety of topics are highlighted (for instance, on the free trade agreement CETA in October 2016), and the position of the candidate is emphasized. Van der Bellen combined the presentation of new posters with an opportunity to position himself, e.g. in May or in August 2016. In April 2016, he presented himself with a sign reading "I am a feminist....Because women's rights are human rights".

Image types such as meeting politicians ( $\mathrm{n}=11$; which showed the candidate together with regional governors or federal ministers either in a conversation 


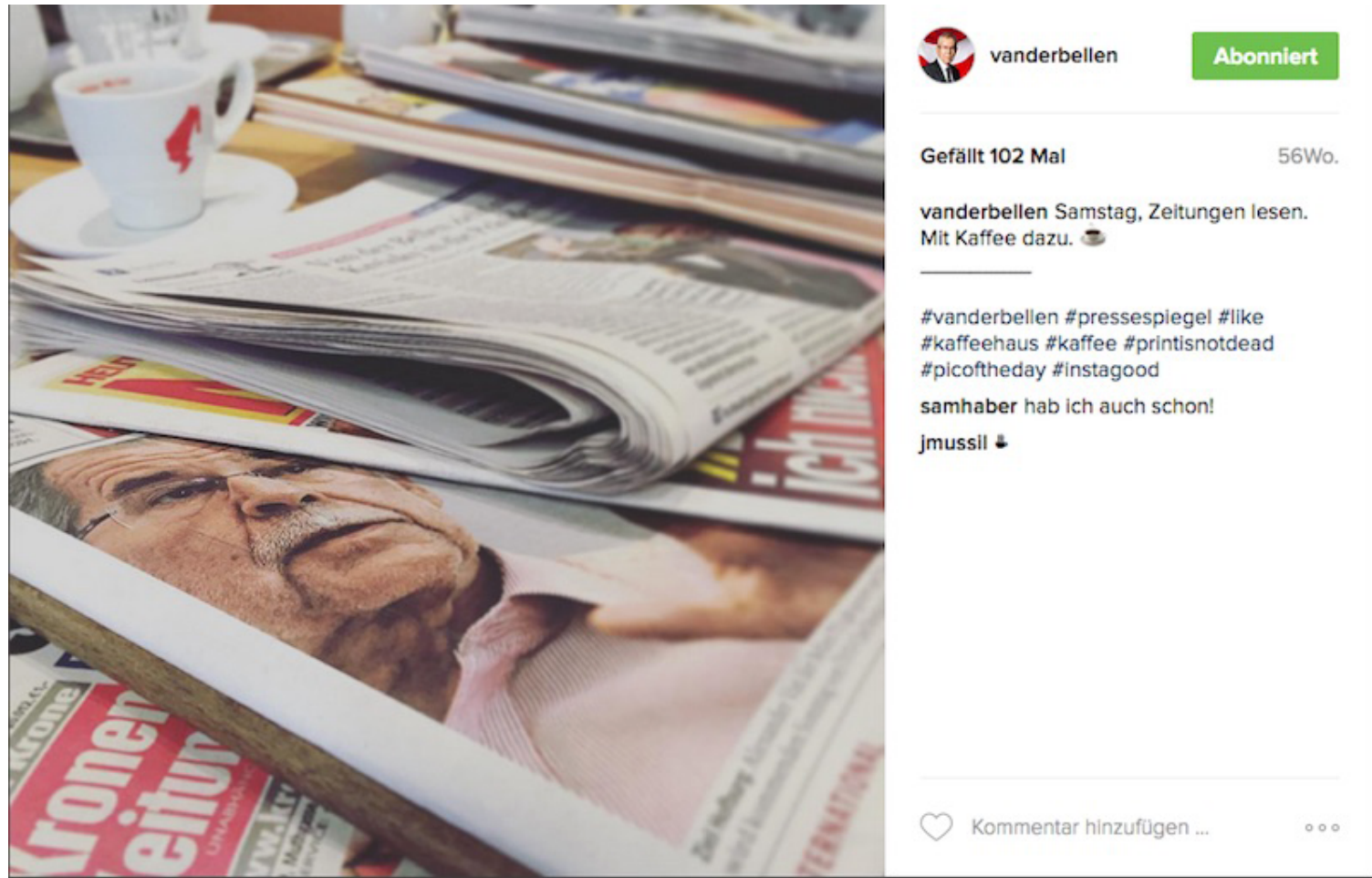

Figure 5. Coffee and Newspapers, posted on 9 January 2016.

or welcome ceremony, or shaking hands), discussion ( $n=18$; Van der Bellen was frequently presented in debates with young voters) and endorsement $(n=17$; which showed mostly prominent supporters, e.g. in March, April and May 2016) underscore the political importance of the candidate.

The image type family $(n=14)$ comprises visual imagery in which the candidate and his family are presented in semi-private moments. Marion G. Müller (1997, p. 204) points out that the family strategy is usually applied to support a "common-man image of a candidate" (Müller, 1997, p. 204). Alexander Van der Bellen only started presenting himself together with his wife at the onset of the runoff campaign, e.g. while taking part in a hike with journalists in the Tyrolean mountains in August 2016 or going for a walk in the Tyrolean Kauner valley in September 2016 and in Lustenau (Vorarlberg) in October 2016. On election day, Van der Bellen and his wife Doris Schmidauer posed in front of the Austrian flag to thank supporters before casting their votes.

\section{Conclusion and Outlook}

Starting from the premise that the production, selection, and distribution of visual imagery may help to shape and manage political images, this article has examined the use of the digital platform Instagram during the Austrian federal presidential election 2016. At the center of interest was the strategic use of the platform as campaign channel by successful runoff candidate Alexander Van der Bellen. Visual imagery on Instagram was classified with an image type analysis (cf. Grittmann \& Ammann,
2009,2011 ) in order to reconstruct underlying selection routines and visual strategies.

What can we learn about political communication when we focus on Instagram? Henry Jenkins stated that in storytelling, "each piece of media adds something significant to the overall experience of the story world" (Jenkins, 2017, p. 1062). What does Instagram add? This article has demonstrated that the strategic selection and presentation of visual imagery on digital platforms can be considered a crucial factor for the delivering of political stories. Selection routines provide important information about the relevance of an image type for the candidate and for the overall campaign narrative. Politicians show different aspects of their personalities, their qualifications for the office, or their understanding of politics than they articulate in verbal or textual form. Since the emphasis on specific image types does not only reveal how a candidate wants to be seen, but also which policies he wants to advocate, in-depth knowledge about strategic visual imagery on politicians' Instagram feeds can advance our understanding of political communication. Furthermore, the reception situation of Instagram imagery can be considered a crucial factor as soon as it comes to the projection of "authentic" imagery. Michele Zappavigna explains that "the temporality of the social network to which these images are posted as chronologically unfolding stream of content, privilege a 'you could be here with me' style of photography since the ambient viewer may view the image in 'real-time' as soon as it is posted" (Zappavigna, 2016, p. 283).

The visual analysis of Alexander Van der Bellen's Instagram posts has shown an emphasis on specific image 
types. The salience of these image types allows for the reconstruction of underlying visual strategies: (1) the highlighting of the candidate's biography (biographical strategy), (2) the presentation of his campaign team (team strategy), and (3) the presentation of the candidate as a legitimate office holder (incumbent strategy).

(1) Biographical Strategy: Van der Bellen used background stories to draw attention to personal qualities, competences, and experiences that qualified him for the office of Federal President. He took his family's refugee background as the starting point for a story of home and togetherness and anchored this story in the Tyrolean Kauner Valley. However, he also underlined the image of an intellectual and university professor. He browsed books, gave interviews in libraries, solved Sudoku puzzles, or exhibited his coffee cup in front of a stack of newspapers;

(2) Team strategy: Van der Bellen put a focus on the presentation of his campaign team, which consisted largely of young supporters. He thereby made the work behind the campaign visible, emphasized his good relationship with his staff, and presented his election campaign as a collective effort and a joint success;

(3) Incumbent strategy: Van der Bellen, in the second half of the campaign after the annulment of the first runoff by the Constitutional Court, acted as if he was already president: he wished pupils a good start to the school year, he attended a national soccer team game, he held a press conference on the National Holiday and delivered a video message in which he recited the words of the federal anthem. With this strategy, Van der Bellen presented himself as the legitimate office holder who had won the election once and considered his re-election a logical consequence.

McNair (2016, p. 509) states that "in social networking...political actors must be able to use the tools efficiently, conveying an up-to-date, tech-savvy image". This analysis shows that Van der Bellen used Instagram as campaign channel in a highly professional way. On the account, the entire campaign could be observed with the help of chronological entries and numerous references as visual diary. These included announcements of events (e.g., start or end of campaign events, site visits, hiking tours with journalists), references to other campaign channels (e.g., Facebook-Livestreams), to new promotional materials (e.g., posters or window flags), to new services (e.g., WhatsApp-Service or Selfie App) or to the campaign fan shop (fanderbellen.at; page no longer accessible). Instagram was also used for calls (e.g., to sign declarations of support or to collect donations) and served to highlight important statements and quotations of the candidate. Thus, the account followed several functions that Filimonov et al. $(2016$, p. 3) have iden- tified for the use of Instagram as a strategic campaign tool: (1) it serves to disseminate campaign messages, (2) it helps to mobilize voters, (3) it is used for image management, and (4) it amplifies and complements other campaign channels (Filimonov et al., 2016, p. 3).

Further research on digital storytelling in the field of political communication may help to examine and compare image types on different platforms, to examine the use of specific image types across platforms, or to analyse which types of images illicit the most engagement. In the introductory chapter to the publication "Storytelling and Politics", Caren Schnur Neile (2015, pp. 1-14) focuses on the importance of tracing transmedia storytelling which unfolds across multiple media platforms. Further research is needed to understand how political stories spread across platforms and how specific platform affordances influence the ways in which these stories are visually rendered.

\section{Acknowledgements}

The article is based on results of a research project funded by the Anniversary Fund of the Austrian National Bank ("The Austrian Presidential Elections 2016: A Case Study in Visual Political Storytelling"; study period: February 2017-January 2019; project lead: Karin Liebhart, researcher: Petra Bernhardt). The authors would like to thank the anonymous reviewers and the editors for their helpful and constructive comments that greatly contributed to improving the article. A comparative analysis of several posts by presidential candidates Alexander Van der Bellen and Norbert Hofer was conducted for an article in the Austrian journal "SWS Rundschau", February 2017.

\section{Conflict of Interests}

The authors declare no conflict of interests.

\section{References}

Balmas, M., \& Sheafer, T. (2016). Personalization of politics. In G. Mazzoleni, K. G. Barnhurst, K. Ikeda, R. C. M. Maia, \& H. Wessler (Eds.), The international encyclopedia of political communication volume II (pp. 944-952). Hoboken, NJ: Wiley Blackwell.

Bode, L., \& Vraga, E. K. (2017). Studying politics across media. Political Communication. doi:10.1080/ 10584609.2017.1334730

Bucy, E. P., \& Grabe, M. E. (2009). Image bite politics: News and the visual framing of elections. Oxford: Oxford University Press.

de.statista.com. (2017a). Statistiken und Daten zu Instagram [Statistics and data about Instagram]. Retrieved from https://de.statista.com/themen/2506/ instagram

de.statista.com. (2017b). Anzahl der Instagram-Accounts in Österreich in ausgewählten Monaten von Dezem- 
ber 2014 bis März 2017 [Number of Instagramaccounts in Austria using the example of selected months in the space of time from December 2014 to March 2017]. Retrieved from https://de.statista.com /statistik/daten/studie/512380/umfrage/instagramnutzer-in-oesterreich

Filimonov, K., Russmann, U., \& Svensson, J. (2016). Picturing the party: Instagram and party campaigning in the 2014 Swedish elections. Social Media+Society, 2(3), $1-11$.

Garzia, D. (2014). Personalization of politics and electoral change. London: Palgrave Macmillan.

Glantz, M. (2013). Instagram. In K. Harvey (Ed.), Encyclopedia of social media and politics (pp. 694-696). Los Angeles, CA: SAGE.

Grittmann, E. (2007). Das politische Bild. Fotojournalismus und Pressefotografie in Theorie und Empirie [The political image. Photo journalism and press photography in theory and research]. Cologne: Herbert von Halem Verlag.

Grittmann, E. (2012). Der Blick auf die Macht. Geschlechterkonstruktionen von Spitzenpersonal in der Bildberichterstattung [Looking at power. Gendering of leaders in visual coverage]. In M. Lünenborg \& J. Röser (Eds.), Ungleich mächtig. Das Gendering von Führungspersonen aus Politik, Wirtschaft und Wissenschaft in der Medienkommunikation [Unequally powerful. Gendering of leaders in politics, economy, and science] (pp. 127-171). Bielefeld: Transcript Verlag.

Grittmann, E., \& Ammann, I. (2009). Die Methode der Quantitativen Bildtypenanalyse. Zur Routinisierung der Bildberichterstattung am Beispiel von 9/11 in der Journalistischen Erinnerungskultur [The method of quantitative image type analysis. On routines in visual press coverage. The example of $9 / 11$ in journalistic rememberance]. In T. Petersen \& C. Schwender (Eds.), Visuelle Stereotype [Visual stereotypes] (pp. 141-158). Cologne: Herbert von Halem Verlag.

Grittmann, E., \& Ammann, I. (2011). Quantitative Bildtypenanalyse [Quantitative image type analysis]. In T. Petersen \& C. Schwender (Eds.), Die Entschlüsselung der Bilder [Decoding of images] (pp. 163-178). Cologne: Herbert von Halem Verlag.

Highfield, T., \& Leaver, T. (2016). Instagrammatics and digital methods: Studying visual social media, from selfies and GIFs to memes and emoji. Communication Research and Practice, 2(1), 47-62.

Holtz-Bacha, C., Langer, A. I., \& Merkle, S. (2014). The personalization of politics in comparative perspective: Campaign coverage in Germany and the United Kingdom. European Journal of Communication, 29(2), 153-170.

Hunt, K. J. (2015). Political storytelling and the land of make-believe. Huffington Post. Retrieved from http://www.huffingtonpost.co.uk/kevin-j-hunt/polit ical-storytelling_b_6895174.html

instagram-press.com. (2017). Website. Retrieved from https://instagram-press.com

Jenkins, H. (2006). Convergence culture: Where old and new media collide. New York, NY: New York University Press.

Jenkins, H. (2010). Transmedia storytelling and entertainment: An annotated syllabus. Continuum: Journal of Media \& Cultural Studies, 24(6), 943-958.

Jenkins, H. (2017). Voices of a new vernacular: A forum on digital storytelling. Interview with Henry Jenkins. International Journal of Communication, 11, 1061-1068.

Karvonen, L. (2009). The personalisation of politics: A study of parliamentary democracies. Colchester: ECPR Press.

Kavoori, A., Lashley, M. C., \& Creech, B. (2017). Voices of a new vernacular: A forum on digital storytelling. Introduction. International Journal of Communication, 11, 1057-1060.

Keim, N., \& Rosenthal, A. (2016). Memes, big data und storytelling. Rückblick auf den digitalen USWahlkampf 2012 [Looking back on the digital US eletion campaign 2012]. In C. Bieber \& K. Kamps (Eds.), Die US Präsidentschaftswahl 2012 [The US presidential election] (pp. 307-330). Wiesbaden: VS.

Kriesi, H.-P. (2012). Personalization of national election campaigns. Party Politics, 8(6), 825-844.

Laestadius, L. (2017). Instagram. In L. Sloan \& A. QuanHaase (Eds.), The SAGE handbook of social media research methods (pp. 573-592). Los Angeles, CA: SAGE.

Marland, A. (2012): Political photography, journalism, and framing in the digital age: The management of visual media by the Prime Minister of Canada. The International Journal of Press/Politics, 17(2), 214-233.

McNair, B. (2016). Image, political. In G. Mazzoleni, K. G. Barnhurst, K. Ikeda, R. C. M. Maia, \& H. Wessler (Eds.), The international encyclopedia of political communication volume II (pp. 505-513). Hoboken, NJ: Wiley Blackwell.

Müller, M. G. (1997). Politische Bildstrategien im amerikanischen Präsidentschaftswahlkampf, 18281996 [Visual political strategies in the context of US presidential election campaigns, 1828-1996]. Berlin: Akademie Verlag.

Müller, M. G., \& Geise, S. (2015). Grundlagen der Visuellen Kommunikation [Basic principles of visual communication]. Munich and Konstanz: UTB.

Muñoz, C. L., \& Towner, T. L. (2017). The image is the message: Instagram marketing and the 2016 presidential primary season. Journal of Political Marketing, 1-29. doi:10.1080/15377857.2017.1334254

Panofsky, E. (1972). Studies in iconology. Humanistic themes in the art of the renaissance. Boulder, $\mathrm{CO}$ : Westview.

Russmann, U., \& Svensson, J. (2017). Interaction on Instagram? Glimpses from the 2014 Swedish elections. International Journal of E-Politics, 8(1), 50-66.

Schill, D. (2012). The visual image and the political im- 
age: A review of visual communication research in the field of political communication. Review of Communication, 2, 118-142.

Schnur Neile, C. (2015). Introduction to the special issue: Storytelling and politics. Storytelling, Self, Society, 11(1), 1-14.

Sylvester, E. (2012). Instagram emerges as a political communications medium. The Heritage Foundation. Retrieved from http://www.heritage.org/node/ 3253/print-display

Van Aelst, P., Sheafer, T., \& Stanyer, J. (2011). The per- sonalization of mediated political communication: A review of concepts, operationalizations and key findings. Journalism, 13(2), 203-220.

Weber, S. (2016). In a political game all about storytelling, which candidate is using narrative to get ahead? Quantified Communications. Retrieved from http:// www.quantifiedcommunications.com/blog/storytell ing-in-politics

Zappavigna, M. (2016). Social media photography: Construing subjectivity in Instagram images. Visual Communication, 15(3), 271-292.

\section{About the Authors}

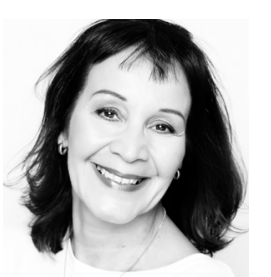

Karin Liebhart is a researcher and senior lecturer at the Department of Political Science at the University of Vienna, Austria, and associate professor of sociology at the University of Trnava, Slovakia. Among her major research interests are visual political communication, discursive and visual representations of politics, and political campaigning.

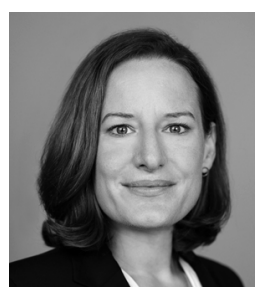

Petra Bernhardt is a researcher and lecturer at the Department of Political Science at the University of Vienna, Austria. Her major research interests are visual politics and strategic political communication in a digital age. 